\title{
Khawaja Yusuf Hamadānī: His Life, Thoughts and Contribution to the Contemporary Sufism
}

\author{
Fatkhiddin Mansurov \\ Center for Modern Languages \& Human Sciences \\ University Malaysia Pahang, Malaysia
}

\begin{abstract}
This study investigates the thoughts and contribution of prominent Sufi scholar Khawaja Yusuf Hamadānī (d. 535 H/1140). He played an important role in the formation of Sunni Sufism that had extended to our present time and nurturing great scholars of all times. He remained among the people, taught the religion of Islam to everyone without discrimination, guided and delivered his admonitions to his people in a proper way. Yusuf Hamadān̄ preferred these deeds over seclusion which was quite popular in the previous decades among Sufis. He has become one of the Sufi Masters with the most number of disciples and educated Sufi leaders such as Khawaja Abdulkhāliq Ghijduwān̄ (d. 575 H/1179) and Khawaja Ahmad Yasawi (d. 562 H/1166) being the founders of the two renowned Sufi orders the Khawajagan-Naqshbandiyya and Yasawiyya that played significant roles in upholding Sufism to the present days. The study is considered as one of the significant research works conducted on Yusuf Hamadān's life, teachings and his contribution to contemporary Sufi thought.
\end{abstract}

\section{Introduction}

Khawaja Yusuf Hamadānī, who was one of the mystic scholars and played a vital role in the development of the Sufi orders in Central Asia. His activities in Central Asia yielded the most efficient results and generated great Sufis and founders of mysticism.

He was a symbol of tolerance, compassion and generosity. He used to distribute what he gained to poor and needy people with no expectations from people. He never got tired or bored of tackling other's problems and would endeavour to help everyone regardless of their condition or race. His heart was full of love and compassion towards all creations. Khawaja Yusuf Hamadānī used to visit non-Muslim houses and tell them about Islam. He would pay more attention and care to poor people than riches. $\mathrm{He}$ was patient and tolerant for everything, and show respect and love to everybody.

Khawaja Yusuf Hamadān̄̄s teaching has been influenced the Muslim countries that played a significant role in the formation and development in their Sufi orders. Despite this fact, it is clearly seen that Hamadānī's life, works and contributions to Sufism had not been studied as much as other Sufi masters.

\section{His Life and Unique Characteristics}

Yusuf Hamadānī was born in $440 \mathrm{H} / 1048$ in Buzanjird near Hamadan. Buzanjird was a village located in $30 \mathrm{~km}$ from Hamadan in present Iran [1]. His full name is Abu Ya'qub Yusuf ibn Ayyub ibn Husain ibn Vahra Buzanjirdī Hamadān̄̄ [8]. Yusuf Hamadānī acquired his primary education and learnt some fields of Islamic knowledge in Hamadan before the age of 19. Later he improved his knowledge in the presence of Abu Ishaq Shirāzī (d. 476 H/1083) in Baghdad. During the years Hamadān̄ spent in Baghdad his tendency to Sufism perfected. After the death of Shirāzī in 1083, he migrated to Hamadan. According to the sources, Hamadān̄i spent his life in the cities such as Baghdad, Marv, Bukhara and Samarqand by narrating hadith and teaching Sufism. It should be stressed that he was renowned through the entire Muslim World as a grand scholar [8].

The most reliable information about Yusuf Hamadānī's life can be found in the book named "KitÉb al-Ansāb" written by Abd al-Karim ibn Muhammad al-Sam'ān̄̄ (d. 562 H/ 1167). Shamsuddin ibn Khallikān stated similar information with some supplements in his book "Wafāyāt alA'yÉn" [21]. Sam ānī had a direct communication with Khawaja Yusuf Hamadān̄ and heard and recorded several hadith from him (narrated by Yusuf Hamadānī) consisting of more than twenty chapters [8].

Ibn Asākir (d. 570 H/ 1175) was a Sunni Scholar, a historian and a student of the Sunni mystic Abu Najib Suhrawardī, states mentioned in his book "Arba '̄nāt" that he heard Yusuf Hamadānī's conversations in Marv in $531 \mathrm{H} / 1137$ [24].

Though several researches had been undertaken to describe in more detail Yusuf Hamadānī's life, yet, the limited information and its variedness had led to a variety of conclusions. It is important to emphasise Madelung's research suggested different approaches from other researches. That approach 
discusses whether Yusuf Hamadān̄ influenced Central Asia Sufism. Although all the researches attempted to benefit from the sources concerning Yusuf Hamadān̄ emphasised his role in Central Asia's Sufism, Madelung put them under doubts [19]. Furthermore, Madelung proposed that there was an attempt to exploit Hamadānī to defend the Hanafi doctrine by showing him as a representative of that doctrine and stressing disagreement in Yusuf Hamadān̄̄'s name.

It should be noted that it is very hard to draw the entire conclusion based on Sam'ānī's brief information. As an author of biographies, Sam 'ān̄̄ might not give sufficient information about Hamadānī's life. Moreover, there was a rivalry between Hanafi and Shāf $i \bar{\imath}$ doctrines. There are no reports in the "Maqāmāt" that regards him as "Hanafı" except for relating his name to Abu Hanifa Nu'mān ibn Thābit (d.150 H/ 767) [14]. There might be some attempts in manuscripts to relate the name of Yusuf Hamadānī to Abu Hanifa in the following centuries. However, this information is not sufficient to count other sources as non-reliable and unauthentic.

Khawaja Hamadān̄'s relationship is stated in the book of Khawaja Muhammad Pārsā (d. 864 H/ 1460) named "Fasl al-Khitāb li Wasl al-Ahbāb fi alTasawwuf" as: "He was a follower of Imam A'zam Abu Haniffa's doctrine" [20]. Since there is lack of information to confirm this, it is hard to agree with this opinion.

While he was studying with Abu Ishaq Shirāzī, Hamadānī was distinguished by his intelligence and talent and became his teacher's closest student. His curiosity and interest in dialectics continued up to the time of adopting an intensely ascetic way of life, though he was rarely involved in the debates concerning Islamic jurisprudence. His lack of involvement in dialectics as a representative of the Shäfi $i \bar{l}$ doctrine eased his acceptance in Central Asia where the Hanafi doctrine was dominant [22].

\subsection{Becomes a Sufi}

The period in which Hamadāni lived saw the sciences of debate, logic, argumentation, and rhetoric strive especially concerning religion be it amongst Muslims or with non-Muslims. Of particular note was the theological dispute that took on threatening political significance between the Hanbali and Shäfi $\bar{l}$ doctrine followers. Sure enough Yusuf Hamadānī who was creative and interested in debates on jurisprudential matters was influenced by these conditions and to an extent was involved in these incidents. However, he lamented the constant bickering between the two schools and decided instead to invest his time and talent in Sufism to which end he dedicated the remainder of his life [5].

Yusuf Hamadān̄̄ being Abu Ishaq Shirāzī's greatest student had probably involved in dissension to certain extent with regrets, that made him dedicated the rest of his life to Sufism. Taking into account the death of all his hadith scholars around $463 \mathrm{H} / 1070$ who reported the narrations, we can assume that he did not study at Nizāmiyyah until Abu Ishaq Shirāzì's death in 476 H/ 1083 [23]. It should be emphasised that reports about the intensification of the occurrence of chaos (fitnah) and disagreements at Nizämiyyah support this assumption. Namely, Hamadānī turned to Sufism after having been influenced by serious discord between the different doctrines.

He received his primary knowledge concerning Sufism from Abu Ali Farmadī (d. 477 H/ 1084). As most scholars agree, he was among the prominent Muslim scholars and great saints who lived in the $11^{\text {th }}$ century. In some sources, his name is reported as Farmazī. Though, his name appears as "al-Farmadī" in the book of Sam'ānī named "al-Ansāb". He was born in the village of Farmad in Tus present Iran [8]. Abu Ali Farmadī was a recognised and sophisticated figure among the Sufis. He focused on nurturing disciples and delivering preaches. He was famed and honoured as a preacher of Khorasan. Yusuf Hamadān̄i received training and knowledge of Sufism from him in Baghdad [9].

A. Khismatulin reports the following excerpt concerning the statement mentioned above: "Sheikh Abu Ali Farmadi was not only the Master of Yusuf Hamadānī, but he was the Master of Abu Hamid alGhazāli as well" [3]. The authors who do not belong to the lineage of Khawajagan also asserted in their books that Imam Ghazālī and Yusuf Hamadān̄ were the disciples of Sheikh Abu Ali Farmadī with the time difference of 10-15 years [3].

In Sufism, it is natural for a Sufi to receive knowledge from different masters or participate in their discourses at the same or different times. Therefore, it should be considered quite normal for Hamadānī to obtain knowledge from different scholars of his time and participate in the inner circles of their discourses. However, his principal teacher in Sufism and science was Farmadī. Thus, Hamadān̄̄'s name is mentioned immediately after Farmadī in the lineages of the Naqshbandiyya and Yasawiyya orders.

When we analyse the narrations and look through Hamadān̄̄'s work Rutbah al-Hayāt [15], it is evident that he was nurtured from the knowledge spring of famous and great Abu Ali Farmadī. Farmadī is considered a scholar who initiated theoretical Sufism and religious order based on Sharia.

\subsection{Yusuf Hamadānī's Travel to Central Asia}

One of his disciples, the famous historian Abd alKarim ibn Muhammad al-Sam 'ān̄̄ (d. 562 H/ 1167) recorded in his book "al-Ansāb" that he attended his classes and learnt from him in Marv. Consequently, 
Sam 'ān̄i studied with him after 525 H/ 1132 [8]. In addition, Ibn Asākir (d. $571 \mathrm{H} / 1176$ ) also listened to Hamadānī's lectures in 531 H/ 1137 [24]. Unfortunately, due to insufficient information recorded in these two famous historians' books about Hamadānī's life in Central Asia, the information given about this Sufi and religious scholar in other historical books is limited.

Yusuf Hamadānī who was creative and interested in debates on jurisprudential matters was influenced by these conditions and somehow involved in these incidents but later he started feeling unpleased about this atmosphere. This condition could be considered as a chief reason for him to devote the rest of his entire life for Sufism. He migrated to Samarqand, the centre of knowledge and wisdom of that time, with his 11 disciples after Baghdad. In sources, there is no statement or comment about why he came to Central Asia. However, it is more than likely that the chief reason of his migration to Bukhara was the strong tendency of Central Asia people to Sufism and keeping themselves out of disagreements between different doctrines [2].

As stated in "Maqāmāt-i Yusuf Hamadān̄̄", HamadānÊ travel to Samarqand from Hamadān with his eleven students [14]. This indicates that he first returned to Hamadān from Baghdad, and after that he travelled to Samarqand. However, we could not find information, why he wished to leave for Central Asia from Hamadān. One of the key factors of their migration to Central Asia was moral values of the people residing there. This facilitated the entrance of Hamadānī and his people into this region. The lifestyles of inhabitants of that region impressed Arab historians and geographers and left good memories in their minds. The people of Central Asian lived as a single family, entering each other's houses without any hesitation and keeping their doors always open to others [10].

In addition, discord and unpleasant discussions between doctrines in Baghdad and restrictions on Sufis caused Sufis to abandon this centre. Apart from these, Hanbalīs had long opposed the Sufis. Such conditions caused the migration of Sufis to Central Asia where they could freely perform their activities and advance their path.

John Bennett (d. 1974) attempted to give detailed information about the grand and religious scholar's life. He stated that Yusuf Hamadānī moved to Bukhara from Hamadān with his eleven students in 473 H/ 1080. He also mentioned that Sultan Sandjar sent to Central Asia, Hamadānī's association, a considerable amount of money (probably golden coins in that time) and suggested him to move to Merv from Bukhara [2]. It should be noted that in 507 H/ 1114, Sultan Sandjar received complaints from people about Muhammad Khan ibn Suleiman's oppression and came near Amudarya (a major river in Central Asia) and accepted his apparent surrender, and then returned without fighting [8]. It is more than likely that he sent the letter to Yusuf Hamadānī during that period. In the "Maqāmāt", GhijduwÉnÊE recorded that Sultan Sandjar consigned the letter to Samarqand through Qasim ibn Jūqī on 1111. His consignment of 50000 dinar to Khawaja Yusuf Hamadānī's association in Bukhara was also stated in the Maqāmāt [14]. However, the succeeding statement that stated his suggestion about moving to Marv was abandoned.

According to the nature of the letter, Sultan Sandjar heard about the high station of Yusuf Hamadān̄i in Sufism and then consigned a considerable amount of money or golden coins with the purpose of receiving prayer (dua) from Hamadānī and the religious scholars around him. Furthermore, he said that he could not come to Samarqand because Suleiman Shah was on the way to attack him. Beside this, Sultan Sandjar inquired from the learned in Samarqand to write a reference letter concerning Yusuf Hamadān̄̄'s good conducts, traits and conditions [14]. Unfortunately, we do not possess any recorded information about the letter to him. Though, as the "Maqāmāt" was dedicated to information about Hamadānī's personality and morality, it seems that the response to Sultan Sandjar's question was preserved in the essence of this latter book. Sandjar was in discord with the ruler of Samarqand, Muhammad Khan ibn Suleiman ibn Dawud, but mistakenly, he was reported as Suleiman Shah in "Maqāmāt" [14]. According to that report, Yusuf Hamadānī's glory and eminence was spread excessively among the people and drew the ruler's attention and gained their admiration.

Reporting from Sam'ān̄̄, al-Dhahabī stated that up to the time Hamadānī encountered a Sufi named Hasan Simnānī, he was accustomed to secluding himself from worldly affairs for periods of around five years [12]. During this time, he travelled to different regions and devoted his time to nurturing disciples.

Hamadānī would always recommend the path of the Prophet Muhammad (p.b.u.h.) and his companions to those who loved and followed him. His heart was full of love and compassion towards all creations. He used to visit non-Muslim houses and tell them about Islam. He would pay more attention and care to poor people than rich. He was patient and tolerant for everything and show respect and love to everybody. He would tell about good virtues and devotion of the four great Caliphates to his followers and admirers [13].

\subsection{His Works and Philosophical Thoughts}

Khawaja Yusuf Hamadān̄̄'s works on Sufism are considered a core factor in understanding of his philosophical thoughts. Yusuf Hamadānī's works are written in accordance with the Qur'an and Sunna and mainly cover the principals of Sufism and are explained in simple language. Yusuf Hamadānī’s 
literary work consists of complete Sufism, good conduct and Islamic knowledge, and they are written in a concise and compact way. He devoted most of his time to nurturing his students' education and he did not attempt to author books on a large-scale. Yusuf Hamadān̄̄'s scientific and literary heritage comprises small-scale works and articles dedicated to Sufism.

Yusuf Hamadānī's literary work consists of complete Sufistic beauty, good conduct, and Islamic knowledge, and they are written in a concise and compact way. Yusuf Hamadānī devoted most of his time to nurturing his disciples and his students' education and he did not attempt to author books on a large-scale. Similarly, as he was a famous and prominent figure throughout the Muslim world, Ghazāli is distinguished among the grand scholars and Sufis of his time on account of authoring many books.

Yusuf Hamadānī's scientific heritage includes small works dedicated to Sufism. Of course, not all of these works were written by Hamadānī, but it would be fair to assume that a part of them are the works of his students, written based on Hamadānī's talks and then consolidated, as his life was mainly dedicated for teaching in lodges, giving scholarly talks in Sufism and praying to Allah [12]. Among them, Rutbah al-Hayāt is worth special attention [15]. In this work, Hamadānī widely elaborated his views on the belief and Sufism. The only copy of the transcript is stored in a collection of transcripts under the number of 2910 at Hagias Sophia library of Sulaimaniyyah Fund in Istanbul. This work is written on the pages $257 \mathrm{a}-289 \mathrm{~b}$ of the collection. On page 367 , it is said that the manuscript was copy-written in $706 \mathrm{H} / 1306$.

This work was published by Muhammad Amin Riyahi in Iran in 1362 [23]. There is a research on Yusuf Hamadānī and his work Rutbah al-Hayāt in the introduction. In addition, the work was translated into Turkish and published by Turkish scholar Necdet Tosun and it contains some information about the features and style of Rutbah al-Hayāt [22].

Rutbah al-Hayāt has the features of the writing style, used in the late $7^{\text {th }}$ and early $8^{\text {th }}$ centuries $\mathrm{AH}$. The author presented the issue in the writing through questions and answers. Answering the questions, he used evidences from Qur'an and hadith, as well as literary metaphors, poetic expressions and philosophic summaries.

A comprehensive answer to the question in this work shows that Hamadānī had solid knowledge in Islamic sciences. Although the writing is small, Hamadān̄i expressed meaningful opinions in it. Rutbah al-Hayāt is mainly about ascetic lifestyle and focused on the spiritual and moral behaviour of man. It also discusses the issue of how a Muslim's belief should be and no Islamic jurisprudence issues are expressed in it. We believe the person who reads Hamadānī's works will have a view that if his works had reached our times, many people would benefit from his wisdom.

Rutbah al-Hayāt followed a questions and answers format. It questions eight important issues and answers them in a comprehensive way. At the same time, we notice that while answering the questions, the author elaborates topics closely related to the issue.

His other available works are Risālah fì Anna alKawna Musakhkharun li al-Insān which is a small treatise written in Arabic and describes that the universe is under the control of mankind and his service. It is stored under registry number of 853 in the Fadil Ahmad Pasha Department at Koprulu Library of Istanbul [16].

Hamadānī gives the following meaning to the Quran verse (Surah: Ayat): 'You' in the verse means all humanity, i.e. I created everything in this world for you, because you are in need for everything in the world. I created the other creation as I created you. You are kings and masters of the universe because it is ready to serve you. However, from other side, you are the servants of the universe, because you are in need of it. As I'm not in need for anything, I am above you and everything I have created for you" [16].

While writing the work, he states that the universe is feeble, because it was given for human's service. Man is weak because he depends on every useful matter in the universe. Meaning, the weakness of the universe over mankind is that it is dependent on them. The strength over human being is that they cannot live without the service of the universe.

Khawaja Yusuf Hamadān̄̄'s other work is Risālah dar Akhlāq wa Munājāt which is written in Persian and explains the importance of Sunna and the asceticism. There are two other books associated with Hamadānī called Manāzil al-Sāirīn and Manāzil al-Sälikin, but unfortunately, they have not reached us.

His Sufistic thoughts were principally different from his predecessor. Prior to Hamadānī's period, Sufi teachings were built on khalwah (spiritual retreat), in another words, they propagated ascetical lifestyle. However, Hamadānī was one of the first scholars of Sufism who applied the teaching "Khalwah dar Anjuman" (outwardly to be with people, inwardly to be with God), submitting to Allah through the mass/people. Thus, as an advice of Yusuf Hamadān̄i to his disciple Abdukhāliq Ghijduwānī: "O my son! Close two doors, and open two doors! Close the door of being Sheikh, open the door of service; close the door of privacy, open the door of preach and intercourse!" [5], we can say that publics who engaged the Sufi lifestyle nowadays emphasise the same things strongly and discourages heading/facing to the world. Accordingly, this is one of the founding views of the KhawajaganNaqshbandiyyah order. 
At the same time, Yusuf Hamadānī has shown the path to be "Insan Kämil" (real/complete human) for the modern man who approves every way permissible to reach and satisfy the desires of the ego, and get confused under the pressure of never ending desires and wishes. When we go through the lives of these people who live Sufism, we see that they neither split from the world nor worshipping days and nights by shutting themselves in a place. What is only seen in their life is giving priority to servant hood, giving more importance than other people to supplementary prayers, practicing solidarity among each other more than other people and continues their daily lives. It means they give importance to what is written in these books and at the same time strive to lift their life standards, provide better facilities to families, and mobilise their financial facilities to make Islam practiced in wider geographies. It is known that many high-level businessmen, bureaucrat, engineer, and doctors have adopted Sufi principles as their lifestyle.

\subsection{The Death of Khawaja Yusuf Hamadānī}

Khawaja Yusuf spent the last years of his life in Marv (present Turkmenistan), one of the big cities of Khorasan at that time. The people of Marv requested him to return to their city when he made his last journey to Herat. They admired Yusuf Hamadānī excessively. The reason of their admiration might be that Hamadānī built his Sufi lodge and religious school in Marv. Most probably, because of this reason, he set out from Herat to Marv during the last moments of his life to spend the rest of it there. It was the year of 535/1140. While Hamadānī, was coming back to Marv, he fell sick on the way in Bamiyan, a town which is located between Herat and Khorasan, and he told his disciples to stop there. And the lifetime granted to him came to an end and it was the time to leave for eternal life and meet The Great Beloved One. He was buried there after his demise. However, later his corpse was transferred to Mary by one of his disciples named Ibn al-Najjār and built a tomb in his name [9]. His shrine, remaining within the perimeter of present Turkmenistan, is considered to be one of the most significant places to be visited in Central Asia and Muslim World.

\section{His Contribution to the Contemporary Sufism}

The period of Hamadānī has played a key role in the process of "formalisation" of Sufism. The Sufis who lived during that age developed and reinforced the concepts, views and other aspects of Sufism that had reached them from the past and endeavoured to defend it from various external criticisms. It should be noted that the political situation in the Muslim World bolstered the development process.
At the end of the $12^{\text {th }}$ century and in the $13^{\text {th }}$ century was a fertile and productive period in Sufism history. Sufism from the scientific/theoretical view and from a practical movement reached its peak at this time. Sufi literature also reached its peak and fruitful period. Historically, a few Sufi orders had a significant presence in the region. The Kubrawiyyah, Yasawiyyah, and Khawajagan-Naqshbandiyyah orders were originated in Central Asia [18]. Their histories are interwoven with that of Central Asia. One of the important figures who played a key role in the establishment of the above Sufi orders in Central Asia was Khawaja Yusuf Hamadānī. His teaching has been influenced by Muslim countries and it played a significant role in the formation and development in the Sufi orders [13].

Based on Hamadān̄îs's thoughts, we can say that Sufism aims to nourish the metaphysical side of a human being. Therefore, the most crucial purpose of Sufism is to provide the flourish of faith in the hearts in terms of the key principles of the Qur'an and Sunna (prophetic traditions). In other words, the most attractive, brilliant and wealthy way of sainthood is adhering to Sunna that is following the Prophet Muhammad (p.b.u.h) by concentrating on the prototypical personality of the Prophet of Islam. Hence, Sunna is very significant in Sufism. Whereas, Sufism is the purification of the heart from immoral habits in accordance with the will to reach eternal happiness and peace, to reach out to the level of maturation in morality through saving the heart from negative things, recognition of own and self thoroughly. The Sufi orders can be defined simply as the systematic form of Sufism. In addition to this perspective, in order to be away from sins, to practice with one's knowledge, and to adjust one's heart and intention, practicing becomes more significant notion as much as preaching. Undeniably, practicing in Islam is an essential stage as much as faith due to the faith may be revealed by practice.

Hence, both notions are inseparable concept of Sufism. In contrary to conventional understanding of asceticism, the one of great contribution of Sufism for understanding the Qur'an and Sunna in nowadays is providing to involve religious deeds continuously as an active participant of the contemporary community in the direct light of Qur'an and Sunna. Thus, Muslims who live according to Sufi principles, may join community actively, share their experience and knowledge, help the others and to encourage for establishing the peace in the society. In order to demystifying individuals who are internalizing the regulations of Sufism, should be concentrate on the style of living of the Muslim in the contemporary society in the World. The Muslims have been discussing this understanding what is related to the inner life of believers.

Therefore, divine imperatives, as deeply presented in the Qur'an, constitute the main pillar of this aspect. The Muslim is someone who trusts, a 
candidate of trust worthy future, promises safety to his surrounding, and who has interrelated colourful differences in harmony. The Muslim is an exemplary person, who opens his heart to everyone. He loves everyone and everything for God's sake, breathes love, and creates an aura of love always around him. They evaluate him based on contributions to the well beings of others. The concentration of them is always on 'We' rather than 'I.' Therefore, the Muslims are not selfish, but someone who thinks of others. In this description, the Muslims become a negotiator of 'positive action' and nothing can prevent him from acting and contributing to the community positively. As highlighted earlier, Sufism in general has a direct relationship with everyday life. Therefore, clashes, conflicts and complications in contemporary times may be reduced and the World becomes more peaceful and habitable place for human beings. On the other hand, unfortunately there are misunderstandings in the society regarding micro level difficulties such as individual experiences on Sufism.

\section{Conclusion}

Khawaja Yusuf Hamadān̄̄ was a consistent follower of Sunni scholars, attached himself to the Qur'an and Sunna and dedicated his entire life to knowledge, education and enlightening people. He would teach the secrets of knowledge and spiritual knowledge of Allah to every level of people and always recommend asceticism and piety to his disciples besides acquiring knowledge. Moreover, he would always attempt to practice his religion completely and never neglect any laws of Islam, and he held such thoughts and feelings that did not approve of being drunk spiritually and miracles which are experienced by some other saints. Yusuf Hamadānī taught his views and visions in Sufism to his disciples during the time where Sufism was flourishing and welcomed. His teachings were welcomed with great enthusiasm in Central Asia and explained the religious of Islam and illuminated teachings through the light of Sufism. During the lifetime of Khawaja Yusuf Hamadānī, Sufism and its orders were widely spread and popular throughout the Islamic world. Till this time, Sufism had undertook several stages and initially, it played a vital role in spreading the lifestyle of Muslims, their purpose in this world, being pleased and content with their fate and piety. As a result, during his entire lifetime of enlightenment and guidance, Yusuf Hamadānī held a thought of always remaining with people to serve and remind them to follow the guided path. This thought was boosted by Ghijduwānī and became the basic principle of Khawajagan order and reached the peak point during the time of Bahauddin Naqshband. Therewithal, he has educated many scholars and thinkers. The really eminent scholars who played a significant role in the history of Sufism by educating many scholars laid the groundwork for orders which is considered important until present days like Khawajagan-Naqshbandiyyah and Yasawiyyah.

\section{References}

[1] Algar, A. Abu Ya'qub Hamadānī. Encyclopedia Iranica, USA, 1982.

[2] Bennett, J. The Masters of Wisdom. London, 1995.

[3] Khismatulin, A. Sufizm v Sentralnoy Azii. (Sufism in Central Asia), Science of Academy of Russia Oriental Institute of Sankt Petersburg, Sankt Petersburg, 2001.

[4] Knysh, A. Islamic Mysticism, Sankt Petersburg, 2004.

[5] Tosun, N. Bahaeddin Naksbend, Insan, Istanbul, 2002.

[6] Yilmaz, H. K., Tasavvuf ve Tarikatlar (Sufism and Sufi Orders), Istanbul, 2007.

[7] DeWeese, D., "The Masha'ikh-i Turk and the Khojagan: Rethinking the Links between the Yasawi and Naqshbandi Sufi Traditions", Journal of Islamic Studies, 2(7), Oxford, July 1996, pp. 180-207.

[8] Sam'ānī, 'A. Kitāb al-Ansāb. Dar al-Ihya al-Turoth alArabi, Beirut, 1999.

[9] Al-Safī, A., Rashahāt Ain al-Hayāt, Tehran, 1977.

[10] Al-Bakrī, A., Al-Masālik wa al-Mamālik, Tunis, 2000.

[11] Attār, F. Tadhkirah al-Awliyā (Tezkiretul Evliya), (S. Uludag, Trans.) Istanbul, 2013.

[12] Al-Dhahabī, S., Siyar-u A 'ām al-Nubalā (Vol. 8), Dimashq, 1985.

[13] Fatkhiddin Mansurov and Faudzinaim $\mathrm{Hj}$. Badaruddin., Khawaja Yusuf Hamadānī: The Famous Mutasawif of Ahli Sunnah, Jurnal Hadhari an International Journal, 7 (1), Bangi/Malaysia, 2015, pp. 19-31.

[14] Ghijduwānī, A., manuscript no: 3001, Maqāmāt-i Yusuf Hamadānī, Tashkent, \{n.d.\}.

[15] Hamadān̄̄, Y., manuscript no. 2910, Rutbah al-Hayāt, Istanbul Sulaimaniyya Library, Turkey, \{n.d.\}.

[16] Hamadānī, Y., manuscript no. 853, Risālah fì anna alKawna Musakhkharun li al-Insān, Istanbul Koprulu Library, Turkey, \{n.d.\}.

[17] Hamadān̄̄, Y., manuscript no. 1028, Risālah dar $\bar{A} d \bar{a} b-i$ Tarīqah, Istanbul Istanbul Millet Library, Turkey, \{n.d.\}.

[18] Koprulu, F., Turk Edebiyatinda ilk Mutasavvifler, Ankara, DIV Yayinlari, Turkey, 1981.

[19] Madelung, W., Yusuf al-Hamadani and Naqshbandiyya, Quaderni di Studi Arabi (5-6), 1988, pp. 499-509. 
[20] Pārsā, M., manuscript no. 1449, Fasl al-Khitāb. The Library of Manuscripts, Institute of Orientalism, Academy of Science of the Republic of Uzbekistan, \{n.d.\}.

[21] Ibn Khallikān, S. D., Wafāyāt al-A yān, (Vol. 4), Beirut, 1971.

[22] Tosun, N., Hayat nedir, Istanbul, 1998.

[23] Riyāhī, M. A., Preface of Rutbah al-Hayāt, Tehran, 1983.

[24] Ibn Asākir, A., Tarīkh-i Dimashq, (Vol. 37), Beirut, 1982. 